\title{
Strengthening Education Characters of Environmental Care in The Faculty of Teacherry And Education Pgri University of Ronggolawe (Unirow) Tuban
}

\author{
*Mardi Widodo, Lecture at Faculty of Teachery and Education Ronggolawe Tuban PGRI University \\ mardiwidodo.unirow@gmail.com, ORCID ID : 0000-0003-4859-4234 \\ Usep Supriatna, Lecture at Faculty of Teachery and Education Ronggolawe Tuban PGRI University \\ usepsupri.unirow@gmail.com, ORCID ID :0000-0002-8827-7498 \\ Sumadi, Lecture at Faculty of Teachery and Education Ronggolawe Tuban PGRI University \\ sumadi.unirow@gmail.com,ORCID ID : 0000-0001-5462-7974 \\ *Corresponding Author
}

\begin{abstract}
Concern for the environment is one of the character values needed in protecting and preserving the universe. Seeing the current phenomenon of environmental damage, it is evident that human awareness in protecting the existence of the environment needs to be grown and increased. Forests are damaged due to human needs for housing, industry, factories closer to the area. These factors should be the focus of our thinking about the environment, ecosystem, habitat. Another factor is that all stakeholders have not implemented environmental laws. Efforts to overcome this include ecological education, increasing awareness of the meaning of the environment for humans, adding public green spaces, greening, waste banks, dumping garbage somewhere, recycling waste into materials that are beneficial to humans. All these efforts will be meaningless if they are not supported by government policies in the form of funds, political will, and a legal umbrella that is assisted by legal certainty and law enforcement and justice. This study tries to find information about improving character education for environmental care for high-level students and lecturers. Strengthening character education is the key to maintaining the existence of the Indonesian nation and state. One of them is strengthening environmental character education. Environmental awareness as a reinforcement of character education needs to be improved to create a healthy and comfortable living environment.
\end{abstract}

Keywords: Education, Care, Environment, and the Academic Community

\section{INTRODUCTION}

Global Warming (Global Warming) is a central issue. It has been seen that the damage on land and at sea due to the actions of human hands so that Allah will feel for them part of the (result) of their own actions so that they return (the right path) (QS ar-Ruum, 30:41). The meaning of the above verse illustrates how closely the relationship between human attitudes and the sustainability of the environment in which humans live. Ecosystem balance that will affect human survival is an absolute prerequisite for creating a harmonious life in all aspects, "be it social, economic, and cultural". Development that is "inegralistic and holistic" is an ideal step in creating "harmony and balance of ecosystems" on earth. . In fact, development is more directed or focused on economic aspects and ignores humanist values. The human view of the natural environment (ecosystem) can be divided into two groups, namely immanent (holistic) and transcendent views. According to a holistic view, humans can separate themselves from the surrounding biophysical systems, such as with animals and plants. In addition, there is a functional relationship with these biophysical factors to form a socio-biophysical unit. According to the transcendent view, life is ecologically part of the environment, humans feel separated from their environment, the environment is considered a resource created to be exploited as much as possible (Iskandar, 2001)

Global warming in recent years has become a central issue, this has become the talk of the world community, including in Indonesia. The increase in earth temperature from year to year due to the accumulation of gases in the atmosphere that covers the earth is a natural phenomenon. The existence of global warming is causing the ozone layer to begin to perforate and the thickness of the layer is getting thinner. The result is an extreme and erratic climate change, the existence of several new diseases both 
attacking human, animal and plant life. The occurrence of solar radiation that does not pass through the ozone layer filter so that the earth is getting warmer in temperature. These phenomena, encourage us to find solutions to prevent and inhibit global warming. One of the efforts is to strengthen character education, especially in concern for the environment. Starting with academic activities, such as reflecting thinking, revitalization, and implementing environmental activities. Concern for the environment starts from small things to big things.

Based on the description above, it requires the growth of awareness of the academic community about active participation in preserving and preserving the environment. The principles of deep ecology (Arne Naess in Mudhofir, 2010) are: (1) The welfare and development of humans and non-humans on earth has a value in itself (such as intrinsic value or inherent value). These values are independent of nonhuman values for human purposes; (2) The richness and diversity of life forms contribute to the awareness of their own values as well as their inherent values; (3) Humans do not have the right to reduce their wealth and diversity except to fulfill basic needs only; (4) The development of human life and culture commensurate with a substantial reduction in the human population; (5) Excessive modern human intervention in the non-human world; 6) Therefore, policies must change, in line with efforts to conserve the environment; (7) The main ideological change is respect for the quality of life (ie being in conditions of inherent value); (8) Those who support the points above have an obligation to make changes either directly or indirectly.

Problem Formulation This research aims to explore and study as well as obtain descriptions, analyze and synthesize in a comprehensive and conceptual manner about: strengthening character education of environmental care for students. The problems include:

a) How to Strengthen Character Education of environmental concern in the civitas Academics, Faculty of Teacher Training and Education, University of PGRI Ronggolawe (UNIROW) Tuban?

b) What factors can strengthen and hinder the character of environmental care in the academic community?

Research Objectives This research aims to explore, study, analyze, and describe comprehensively and conceptually. The purpose of this research is basically to find out:

a. Strengthening character education for environmental awareness in the academic community of the Teaching and Education Faculty of the University of PGRI Ronggolawe (UNIROW) in Tuban.

b. Factors that can strengthen the character of environmental concern for the Faculty of Teachery and Education UNIROW Tuban academic community.

c. Factors that can hinder the strengthening of the character of environmental concern in the Faculty of Teachery and Education UNIROW Tuban academic community.

Research Urgency Research with the objective of strengthening character education and environmental awareness is very urgent because the human environment suffers tremendous damage in seconds and minutes. This research also has an urgency to develop the concept of concern for the environment, strengthening character education, and scientific development of the civic of the environment. In the context of civic citizenship, respect and responsibility are needed as humans in maintaining and preserving the natural environment of the universe.

\section{LITERATURE REVIEW}

Strengthening Character Education In character education, Lickona (1992) emphasizes the importance of three components of good character, namely moral knowing, moral feeling or feelings about moral and moral action or moral actions. This is necessary so that students are able to understand, feel and work on the values of virtue. Ratna Megawangi stated that in character education, 9 pillars of character can be taught to children, namely: (1) God's care and truth; (2) Responsibility, discipline and independence; (3) Trust; (4) Respect and courtesy; (5) love, care and cooperation; (6) Confident, creative, and never give up; (7) Justice and leadership; (8) Kind and humble; (9) Tolerance and peaceful concern.

Strengthening character education towards environmental awareness at the higher education level, because in higher education the academic community is required to implement character values. Currently, the condition of the environment is becoming increasingly alarming, on the other hand, human concern for environmental sustainability is decreasing. The balance of environmental ecosystems greatly determines human survival. Integralistic and holistic development is an ideal step in creating harmony and balance in natural ecosystems. In fact, development is more focused on economic aspects alone, and ignores humanist values.

Today there is global empathy in the agenda of environmental preservation (Indra Ismawan, 1999), the four issues, namely: (a) Pollution; including air pollution, acid rain, climate change, water pollution, pollution caused by chemicals, industrial waste, nuclear waste, and so on; (b) Natural 
resources; among others, the issue of deforestation, loss of genetic resources, soil erosion and desertification, critical land problems, damage to marine resources, degradation of land capacity, loss of agricultural lands, and so on; (c) Urban; among others, land use in big cities, environmental sanitation, clean water, urban growth management, social welfare and education, environment and slum housing, greening in big cities, and so on; (d) Management; among others, monitoring and reporting, investment analysis, cost benefit analysis, cost effectiveness (cost effectiveness), risk analysis, also includes (Environmental Impact Analysis) in a project.

Strengthening character education in the learning model of the world of education at the higher education level combines it with character values which include: (1) Religious; (2) Honest; (3) Tolerance; (4) Discipline; (5) Hard work; (6) Creative; (7) Independent; (8) Democratic; (9) National Spirit; (10) Land Care for Water; (11) Appreciate achievement; (12) Communicative; (13) Concern for Peace; (14) Reading pearls; (15) Care for the Environment; (16) Pedulisocial; (17) Curiosity; (18) Responsibility. The character value of caring for the environment becomes an urgency in relation to preserving nature and the existence of humans on this earth.

Theory of Ethics and morality as well as theories of Environmental Ethics Definition of Ethics and morality Theoretically, ethics means "customs", which means "customs" or "habits". Ethics relates to good life habits, good living procedures, both in a person and in society. These good living habits are then carried out in the form of rules, regulations or norms which are disseminated, recognized, understood and taught orally in the community. Morality which means "procedures," customs "or" habits ", in the sense of" customs "or" wisdom ", the word moral has the same meaning as the Greek word" ethos ", which means" ethics".

In Arabic, the word "moral" means character equal to "morals", while in Indonesian, the word "moral" is known as "morality" (Bambang Daroeso, 1989). There are three ways to understand morals, namely: (a) Morals as human behavior; (b) Moral as a set of ideas about life behavior with certain basic colors; (c) Moral is a teaching about good life behavior based on a certain view of life or religion. (DA Wila Huky in Bambang Daroeso, 1989). Some of the Ethical Theory which is the basis of concern for the environment, namely:

Ethics of Deontology The term "deontology" comes from the Greek word "deon", which means obligation, and "logos" means science or theory. To the question of how to act in certain concrete situations, deontology answers: do what is your obligation as revealed in the existing moral norms and values. Deontology ethics emphasizes motivation, goodwill and a strong character to act in accordance with obligations. In fact, according to Kant, goodwill should be judged as good in itself regardless of anything. Good will is an absolute prerequisite for acting morally. The good will becomes a condition that wants or does not want to be fulfilled so that humans can act in a good manner, while at the same time justifying their actions.

Ethics of Teleology The term "teleology" comes from the Greek word "telos", which means goal, "logos" means science or theory. Teleology ethics assesses the merits of an action based on the purpose or the result of the action. An action is considered good if it has good intentions and brings good results. So, to the question, how to act in certain concrete situations, the answer to "teleology ethics" is to choose actions that bring good results.

\section{Ethics of Virtue}

In contrast to the two ethical theories above, virtue ethics does not question the consequences of an action. Also, do not base moral judgments on obligations to universal moral laws. Ethics prioritizes the development of moral character in each person. Aristotle said that moral values are determined and emerge from life experiences shown by big figures in a society in dealing with and responding to life's problems. Thus, virtue ethics places great emphasis on history and stories - including fairy tales and wayang.

Understanding Environmental Ethics Almost all moral philosophers who have an "anthropocentric" view see environmental ethics as a philosophical discipline that talks about the moral relationship between humans and the environment or the universe, and how human behavior should be towards the environment. So, which is primarily the focus of attention to environmental ethics, according to this understanding, is how humans should act or how human behavior is in relation to nature and the moral values and principles that animate human behavior in relation to nature.

Environmental ethics does not only talk about human behavior towards nature. Environmental Ethics also talks about the relationship between all life in the universe, namely between humans and humans that have an impact on nature and between humans and other living things or with nature as a whole. This includes various political and economic policies that have a direct or indirect impact on nature. 
The Essence of Global Warming and Its Direct Impact Global Warming is an event or occurrence of an increase in the average temperature of the atmosphere, sea and land on Earth caused by human activities or natural processes. Scientists have calculated that the global average temperature at the earth's surface has increased by $0.74 \pm 0.18 \mathrm{C}\urcorner(1.33 \pm 0.32 \mathrm{~F})$ during the last hundred years (Abu Fatiah Al-Adnani, 2008). Senior researchers from the Center for International Forestry Research (CIFOR) explained that global warming is the capture of long-wave radiation (also called heat / infrared) emitted by the earth by greenhouse gases (the greenhouse effect is a term for heat trapped in in Earth's atmosphere and cannot spread). These gases are naturally present in the air (atmosphere). The direct impact of global warming for Indonesia, both in the short and long term.

I. The impact of global warming in the short term; in Indonesia, approximately $70 \%$ of air pollution is caused by motor vehicle emissions. Motorized vehicle pollution can have negative impacts, both on human health and on the environment, as well as increase Indonesia's infant mortality rate. Climate change that occurs due to global warming will increase various kinds of diseases in humans, it will also have a direct effect on food security, because plants are disturbed.

II. Some of the effects of global warming in the long term include the following: the sinking of islands and cities, slowly rising sea water to land as high as 1 meter. The sea level rise has the potential to submerge 50 meters of land from the coastline of the Indonesian archipelago. Drought-prone, erratic weather conditions can also cause drought despite high rainfall. Changing climate, shifting seasons due to climate change and changing weather have resulted in drought in some areas. Prone to landslides, there are around 918 landslide locations in Indonesia.

\section{Environmental education as a basis for attitudes and behavior for human life}

Environmental education should be applied in all types and pathways and levels of education from primary to tertiary education. Environmental education must be able to encourage the integration of wisdom, attitudes and behavior in dealing with problems that arise from earthquakes, volcanic eruptions, etc., with damage caused by human behavior. It is also integrated into efforts to reduce or reduce pollution as well as human actions. (Surjani, 2009).

Environmental management is carried out through environmental education whose mission is education of attitudinal, moral and spiritual wisdom in the current and future behavior reality for the safety and welfare of the ecosystem where we are located. Environmental problems are moral problems, human behavior problems. The environment is not just a technical problem. The global ecological crisis that occurs is a moral problem, a global moral crisis. Whereas there are various environmental cases currently occurring, both at global and national levels, mostly originating from human behavior. According to Arne Naess (Sonny Keraf, 2006), the current environmental crisis can only be overcome by changing the way humans perceive and behave towards nature. This means that an environmental ethic is needed that guides humans to interact in a new way in the universe.

Modern society, needs to protect the quality of the environment, biodiversity, and the order of human life. Effective mechanisms are needed including strict regulations, incentives, fines, environmental monitoring and ongoing assessments. The basic values of our society today are often materialistic. To change it, a comprehensive and complementary approach is needed (Wensdalam M.Indrawan, 2007). Environmental Ethics needs to be disseminated to the people of Indonesia, if our society is aware of and adheres to the principles of environmental ethics, environmental preservation and maintenance of biodiversity can run well.

The principles of environmental ethics have been proven by many traditional cultures that exist in our homeland, they have succeeded in blending with the environment, for centuries they have achieved harmony with nature. In this traditional culture, social ethics and norms have encouraged individuals or individuals to take responsibility and utilize natural resources efficiently. Environmental economists have indeed developed methods to calculate the economic value of the environment, but this value is only a potential value, a substitute value, such as the value of biodiversity, genetic value (germplasm), one of which is the raw material for medicines. Human culture can influence human attitudes towards the environment. The teachings of human culture can become the basis of reference for environmentally sound development. The attitude of human life that is oriented towards materialism makes people greedy. For example, forests are exploited for their benefit only for economic purposes without considering: (a) the needs of future generations in the context of economy and natural preservation, and (b) the need to save the forest itself.

Ethical arguments are valid reasons, to protect environmental sustainability and biodiversity. This argument arises from the value order of various religions, philosophies and cultures so that it can be understood by most members of society. Ethical arguments for preserving the environment and biodiversity can touch the instincts and good sides of people. This argument arises from respect for life, 
nature, weakness, a sense of beauty, uniqueness, beauty in the world of life, and belief in God's creation and greatness. The public can often accept it, at least most people can consider this argument in their belief system, argues Callicott (M.Idrawan, 2007).

In a study of previous studies on "Strengthening Character Education for Environmental Care, there are several relevant studies studied to expand discourse in compiling research, as follows: a) Research by Ira Rahmawati and I Made Suwanda (2015), on Formation Efforts Students' Environmental Care Behavior through the Adiwiyata Study Program at Junior High School 28 of Surabaya. The results showed that the study program efforts included: (1) integration of environmental material into all subjects and included in the syllabus in one semester; (2) through self-development in the form of routine activities such as the (Momentarily Picking up) program, Waste Recycling, twenty-one (Work Programs), Class Pickets: (3) spontaneous activities such as reminding students of class picket schedules, participating in invitation to a seminar on environmental studies; (4) exemplary, such as giving examples of environmental care behavior from the campus; (5) conditioning includes the availability of facilities and infrastructure, rules on food hygiene for canteen traders, imposing sanctions on students who do not maintain the cleanliness of the campus environment, installing student drawings on energy saving; (6) (for a moment to collect) and eight plus, one minus, extracurricular. b) Research by Takarina Yusnidar, Dewi Liesnoor, Eva Banowati (2015), Participation of the citizens of the study program in realizing the Adiwiyata program in West Semarang Region Junior High School. The results showed that the study program's efforts in implementing the Adiwiyata program: (1) received a positive response from campus residents; (2) the participation of the residents of the study program in realizing the Adiwiyata program is carried out in waste management; (3) clean and greening activities on Friday; (4) the role of environmental education for study program residents is significant; (5) Lecturers integrate environmental education in certain subjects. c). Jumadil Researcher, Kahar Mustari, Alimuddin Hamzah (2015) Implementation of the Adiwiyata program on Cognitive, Affective and Psychomotor Aspects of Environmental Management for Higher Lecturers in Kendari City. The results of the study: (1) that the knowledge abilities (cognitive), attitudes (affective) and environmental skills (psychomotor) of class VI students of Adiwiyata study program compared to the Adiwiyata study program; (2) and there is a positive influence of the Adiwiyata program on cognitive, affective and psychomotor students' living environment. Departing from the relevant previous research results, it is considered very urgent and urgent if the researcher tries to examine the problem: "Strengthening the Character Education of Environmental Care in Purwantoro 1 State Higher Education Malang City"

\section{METHODS}

Research Design and Methods This research is a qualitative descriptive study, which is basically focused on extracting and studying various literatures on Strengthening Character Education for Environmental Care. With the initial activity of identifying character concepts and environmental theory, this research is designed into two activities. The first activity is exploring data related to efforts to describe the character context and environmental theory that needs to be reoriented and the second is related to the activity of finding and recognizing and describing the strengthening of character education for environmental care to be presented as strengthening character education for environmental care in the academic activism of Faculty of Teachery and Education UNIROW Tuban.

This research is a descriptive-qualitative research, which aims to describe information about the status of an existing symptom, the state of the symptoms according to what they are. The research result data is to describe problem after problem which is the focus of the research. Qualitative research according to Bog and Taylor in Moleong (2000) is a research procedure that produces descriptive data in the form of written or spoken words from person to person and observable behavior. In connection with this research aims to collect information about strengthening character education caring for the environment in higher education.

The research was conducted at Faculty of Teachery and Education academic activism which includes students and lecturers as research subjects. By using data collection techniques: a) in-depth interviews, which aim to gather information about strengthening character education caring for the environment, b) observation, which is a technique of collecting data in the field through careful observation, where researchers directly see the research activities being studied (Moleong 2005). Researchers made observations on: 1) activities of the academic community towards environmental awareness, 2) activities of the academic community in maintaining the environment, c). documentation: this technique is used to strengthen and complement the data from the interview results.

Location and Time of Research Purpasively the location of this study was determined in accordance with the formulated objectives, namely activities to strengthen character education for 
environmental care in the Faculty of Teachery and Education UNIROW Tuban academic community. When the research was conducted in the 2019/2020 academic year. Data and Data Sources The types of data needed in this study include primary and secondary data. Source of data (Key Informants) Faculty of Teachery and Education academic community Data Collection Techniques This research uses a number of methods in data collection. The method in question includes the following methods:

Preliminary Study The implementation of this method is intended to explore information related to knowledge and concepts, and perceptions of strengthening character education of environmental care for students and lecturers or the academic community. Observation Researcher's observation method is carried out in order to observe directly the form or description of the program to strengthen character education for environmental care in the academic community. Indept interview (Inner Interview) Indepth interviews or interviews researchers do to explore concepts, thoughts, or responses of respondents to strengthening character education for environmental care in the academic community Documentation The researcher carried out the documentation method in order to get an overview of activities to strengthen character education for environmental care in the Faculty of Teachery and Education UNIROW Tuban academic community.

Focus Group Discussion (FGD) The FGD method the researchers conducted was in the form of a limited discussion about strengthening the character education of environmental care in the Faculty of Teachery and Education academic community which was carried out with colleagues and experts according to their fields. Data Analysis Techniques Data analysis is described by Lexy Moleong (2006) as a process of organizing and signing the lecturer into patterns, categories, and basic description units so that themes can be found and work hypotheses can be formulated. The data analysis method used in this study is to use the analysis method proposed by Glasser \& Strauss, which includes the following stages: (a) data reduction and identification activities, and data coding, (b) data categorization, (c) synthesis, and (d) preparation of working hypotheses that are formulated in the form of a draft or the concept of strengthening character education for environmental awareness in higher education. Data Validity Criteria In order to test the validity or trustworthiness of the data in this study, the researcher used the following data validity checking techniques: (1) the persistence of the researcher in carrying out observations in the field; (2) Extension to the participation of researchers at the research location; (3) Referential adequacy through checking with references or library sources, as well as other relevant sources; (4) Checking peers in the form of discussion and sharing activities, both with NGOs, related agencies, experts, and peers; (5) Carry out triangulation in the form of cross-checking or croschecking the results of research with data sources, data collection methods used, underlying theory, which are relevant to the research objectives.

\section{DISCUSSION AND CONCLUSION}

Implementation of Strengthening Character Education for Environmental Care In realizing the Strengthening Character Education for Environmental Care program, the Dean plays a very strategic role, because the Dean is a top leader and as a manager. The success of a program in an educational institution such as the Faculty of Teachery and Education is indeed influenced by several components. The leadership component here plays a very important role. Below is a description of the opinions and views of the academic community which include: Deans, Lecturers, and students as follows:

The Dean explained his role in the implementation of strengthening character education for environmental care, as follows:

"... what I did was forming a Faculty Team. This team is a team that plays an important role in the implementation and management of the environment, including involving all elements of the faculty academic community. The participation of the academic community is an important element in the success of environmentally sound programs. These core team members meet regularly. This team member then assigns smaller work groups to carry out daily tasks. This small group can involve the academic community in Faculty of Teachery and Education. Nurturing and preserving activities are carried out on a large and small scale in a planned and programmed campus environment. (Dean)

In line with the explanation of the Faculty of Teachery and Education Dean about his role in realizing the Strengthening of Character Education for Environmental Care, the Lecturer in Charge of the Environmental Care Program described the following:

Cultural-based and environmentally friendly environmental awareness program studies are designed to provide an overview of conditions to the institution. The results of the environmental assessment will inform what Action Plan will be carried out. In addition, environmental assessments will also help determine urgent and needed changes. This will also help set realistic goals and measure the success achieved. Environmental studies by the faculty team cover a variety of environmental issues for 
educational institutions, for example: Garbage- Water- Energy- Food and campus canteens - Biodiversity "(Lecturer 1)

Based on the respondent's explanation above, the role of the Dean is to form a team involving the faculty academic community and stakeholders, as well as designing activities to be carried out and informing the action plan.

\section{Environmental Care Action Plan}

The lecturer argues about the Action Plan, as stated as follows:

"... All of these issues must be observed while the environmental assessment is carried out using a checklist instrument. Checklist containing a series of "yes or no" statements and answers. There is also a special column for writing comments which can then be used to add information and suggestions as well as suggestions for the preparation of a culture-based and environmentally sound Action Plan. What needs to be considered is that every activity must carry out an environmental study in accordance with the conditions and in the best possible way. Involve students (students) as much as possible. Environmental assessments are carried out at a certain time, for example, carried out annually or biennially according to individual needs. This is done to measure and evaluate the progress of the faculty team's performance. (Lecturer 2).

Regarding the Action Plan of the Dean of the Faculty of Teachery and Education, PGRI Ronggolawe University, Tuban argues, as follows:

Action plans are at the core of a cultured and environmentally sound program. This planning is a series of activities and objectives that are scheduled. This planning will also be used as an evaluation material for environmental improvement as a result of the environmental studies that have been carried out. As with every stage of the process with a cultural and environmental perspective, the academic community must be involved in preparing an Action Plan. (Dean)

Another opinion expressed by Lecturer 3 who was in charge of the Environmental Care Action Plan stated as follows:

"The action plan must be developed based on the results of environmental studies that have been carried out previously. Activities are structured with clear objectives, clear deadlines, and clear responsibilities for the activities. This is done for each stage of the activities to be carried out. Apart from that, what is important to do is the various activities that will be carried out by involving the academic community as far as possible linked to the curriculum as a part of the learning process ". (Lecturer 3)

In preparing the Action Plan, the Lecturer in Charge of the Program also argued to strengthen previous opinions. The opinion of the Lecturer in Charge of the Program can be described asfollows:

"In preparing the action plan, one also needs to pay attention to ensuring that the targets set are realistic in accordance with the potential and resources that are owned and can be achieved. Do not be too ambitious and overconfident so that it is difficult to achieve goals because failure to meet targets can result in lower motivation and enthusiasm for cooperation. If the results of the environmental assessment require that an action plan for environmental care needs to establish many goals to be achieved, do not complete them all at once. We recommend that you make a priority scale of activities. Priority activities can be carried out by dividing the goals into short, medium and long term plans. "(Lecturer 1)

Based on the results of the interviews with several respondents above regarding the preparation of the Action Plan, it can be concluded that in order for the Action Plan to be successful, the faculty must conduct an in-depth study, in conducting studies it must involve all components in the faculty, goals must be clear, the program must be realistic and there must also be a clear schedule. In choosing activity topics that support the realization of the strengthening of character education for environmental care according to the priorities of the faculty and try to build good cooperation with parties outside educational institutions

In line with the description above, the Dean added his opinion on how to find out whether the faculty team had achieved the predetermined targets, as follows:

"... to find out whether the faculty team has succeeded in achieving the targets stated in the Action Plan or not, monitoring and measuring the expected progress must be carried out. A continuous monitoring and evaluation process will help ensure that these activities are sustainable. The monitoring and evaluation methods used will depend on the objectives and measurement criteria defined in the Action Plan for each topic. In some cases there will be easy and accurate ways to measure progress, including ": (Dean)

Based on the results of interviews with several respondents above, it can be concluded that to determine the level of success of the environmental awareness program, it is necessary to establish a 
team, prepare the necessary instruments, monitor and evaluate the use of funds spent, monitor all activities or the monitoring and evaluation process. (monev).

In line with the opinion of the Lecturer in Charge of the Program, Lecturer 4 added his opinion as follows:

“... one of the best ways to involve study program residents is to organize routine activities and certain important days (action days). At a certain time, the Day of Action is an opportunity for all residents in the student study program, lecturers and other staff as well as interested parties from the local community, to jointly achieve some of the targets set out in the Action Plan. Days of Action need to be well-planned, both in terms of allocating responsibilities and ensuring that everyone knows about them. Action day is important, but routine activities are also very important. Activities such as recycling, saving energy and water will only be successful if everyone is involved. Involving the wider community in the diwiyata program is very beneficial. Parents of students, local communities, and local government and the business world can be used as references to enrich information, train or help finance activities. Involving the public and the mass media to expand information dissemination, for example by making newsletters, press releases to local media, and so on ". (Lecturer 4)

Student Views and Opinions about Strengthening Character Education Concern for the Environment

Student 1 Trying to be someone who is beneficial to the environment. For example, when there is mutual cooperation, we are not only spectators, we are involved in it. Fostering new innovations. For example, so far a lot of waste is just thrown away without any recycling activities. We can make a waste bank in a small community first. This is very important to do, because the environment is very much needed for society and has a huge influence on human survival.

Student 2 Holds or participates in workshops to deepen the philosophical-theoretical concept of the importance of character education and take effective steps for the continuation of education that is devout (moral), the development of science, technology, harmonious relationships among high-level lecturers and citizens love, care, and mutual cooperation. According to him, in maintaining and preserving the environment, one priority must be to maintain cleanliness by balancing with natural conditions. A clean environment means that it is free from air pollution, water and this fresh cool atmosphere is very good for health and can be a balance to natural life.

Student 3 Forms an organization that fosters the academic community and focuses on how to implement character strengthening as a form of concern for the environment. Maintaining and preserving the environment is very important for the continuity of human life, if the environment is properly maintained and preserved it will fulfill its function. The character of environmental concern becomes an urgent matter in maintaining the continuity of human existence on earth.

Student 4 Form an organization that focuses on caring for the environment as the implementation of character education, namely by holding activities with the theme of awareness and concern for the environment such as greening, car free days. Maintaining and preserving the environment are things that must be prioritized for human health in order to avoid various diseases. As it should be, we have to get used to living healthy, keeping the environment clean by getting used to throwing garbage in its place, not cutting trees carelessly, not throwing waste into rivers, etc.

Student $5 \mathrm{~A}$ form of environmental concern that can be realized, namely through obedience to good rules such as always maintaining cleanliness by not littering, utilizing items that are no longer used (recycled), using natural products such as use by planting organic, do greening the surrounding environment by planting trees. Environmental preservation is very much needed because by maintaining and preserving the environment it can help meet the needs of future generations, the role of the academic community is very important by disseminating actions or ways so that natural resources remain sustainable, namely through awareness of protecting, preserving, protecting and managing them.

Student 6 exemplary in learning, empowering and strengthening environmental awareness, able to understand environmental problems, awareness of attitudes and behavior and increase the desire to actively participate in solving environmental problems. Involving the community to maintain cleanliness, apply a healthy environment, discipline. The academic community plays an important role in activities to maintain and preserve the environment.

Student 7 The implementation of strengthening character education in the Faculty of Teachery and Education academic community has gone well, where the caring attitude between the lecturers and the academic community has gone well, especially during a pandemic such as lectures continue even though online. Forms of activities that can be used to strengthen character education : socialization of concern for the surrounding environment, especially during a pandemic like this, providing a place for washing hands in the campus area, personal awareness to protect and maintain the campus environment, greening or planting plants simultaneously in the campus environment

Student 8 implementation is very good and carried out during class learning. Lectures on environmental concern for the academic community, are described as being active in caring for the 
environment especially during a pandemic. Forms of environmental care activities by maintaining campus cleanliness, maintaining and maintaining environmental sustainability, to support the prevention of Covid 19 are implemented health procedural.

Student 9 The implementation is very adequate, especially in the implementation of environmental awareness character education content in the academic community as in this pandemic, lectures continue but in online form. Maintaining and maintaining cleanliness in the community during this pandemic period, the campus strictly enforces health protocols according to government recommendations, such as wearing masks and checking body temperature.

Student Iinternship implementation has been very good, by doing it in the previous class. At this time, the academic community really cares about the environment even though through online learning activities. The forms of activities carried out are getting used to maintaining cleanliness, maintaining and maintaining the sustainability of the campus environment, disposing of garbage in its place, currently the campus is implementing health SOPs.

Students internship implementation of environmental awareness is adequate, especially in the implementation of environmental awareness character education content in the academic community. Everything is still implemented and carried out both during normal times and during the COVID-19 pandemic. The forms of activities carried out include: maintaining and maintaining environmental sustainability, hand washing habits, conducting socialization about healthy living environments, sustainable environmental care movements.

Based on the results of interviews with the respondents above, it can be concluded that: to familiarize the academic community with light, fun activities related to the environment which in turn will shape the character of environmental care. And how to involve routine activities (action days) for parents and the wider community as well as involving the mass media. This program must also be supported by the availability of funds, both from the campus, government and parents and the community. With regard to funding, the Dean has the following opinion:

"... the availability of a budget for the Strengthening Character Education for Environmental Care Program from the government is very much needed, because to run this program requires a large amount of funds. Support or an injection of funds from the government is needed for the implementation of this Environmental Care Character Education Strengthening Program. Community participation in implementing the Program is needed. Activities like recycling, saving energy and water will work if everyone is involved. So that the community around the campus indirectly moves the conservation and safety of the environment for the benefit of present and future generations ". (Dean)

Inhibiting factors, things that can hinder the running of a program. In connection with the strengthening and inhibiting factors that can affect the Environmental Care Character Education program for students. In connection with the problem of reinforcing factors, Dossen, in charge of the program, said as follows:

"... the supporting factors in the institutional strengthening program for character education for environmental care are supported by the entire academic community which is coordinated according to the job description. Each of them has a role that can mutually reinforce the achievement of a character education strengthening program for environmental care. Awareness of environmental awareness is marked by disposing of garbage in its place, watering the garden ... besides that, there is also a fostering of a waste bank "(Lecturer)

Based on the respondent's explanation above, it can be concluded that several factors strengthen environmental-friendly programs including: supported by a team of faculty, students, lecturers, faculty leaders, the community and stakeholders. Environmental Agency of Tuban Regency and Garbage Bank. Furthermore, with regard to the supporting factors, Lecturer 2 argues as follows:

"... the entire academic community is very enthusiastic about greening the environment by bringing plant seeds from their homes, some are bringing flower seeds and fruit seeds. Each study program has a classroom garden and pickets are formed to care for plants. Weed the grass, fertilize it or water it in the summer (Lecturer 2)

Based on the results of the interviews with the respondents above, it can be concluded that the strengthening factor in the environmental program is the concern of the academic community on a regular basis in greening the campus environment. With high awareness, the academic community brought flower and fruit seeds from home, and made a garden in front of each study program class and held a picket schedule for caring for the garden.

The inhibiting factors for the implementation of the character education strengthening program for environmental care as stated by the Lecturer in Charge of the Program, are as follows:

"....we, as the person in charge of the program, feel that we are lacking in budget. If we want to create infrastructure but with a limited budget, we have to change our minds. There is a budget from the 
institution, but it is very minimal compared to what needs to be realized. Want to attract a rather large amount of funds from the academic community does not allow for campus development funds. (Lecturer 1)

Factors that strengthen and hinder efforts to strengthen character education for environmental care include:

The results of the interviews with the respondents above can be concluded that the inhibiting factor is the limited budget of the institutions that oversee it in realizing the strengthening of character education for environmental awareness. Other inhibiting factors were also conveyed by the Dean, as follows:

"... even though we have been moving quite well and are active, I see there are still some academicians, although not many are still reluctant in maintaining and preserving the environment, for example being asked to picket the garden does not want to go home immediately for various reasons. Asked to bring flower or fruit seeds, he said he forgot, at home there are not many ... there are not many academicians like this but are still under the monitoring of our team ... how will he be aware of the importance of protecting the environment ... (dean).

Listening to and analyzing the results of the above interviews with respondents, it can be concluded that there are factors that hinder this program, although a little, namely: there is a small part of the academic community who is not enthusiastic in implementing environmental awareness programs as an integral part of strengthening character education.

\section{CONCLUSION}

By looking at the various research findings and data exposure accompanied by their discussion in Chapter IV, then in Chapter V, conclusions and suggestions will be presented regarding the results of research on "Strengthening Environmental Care Character Education in Faculty of Teachery and Education UNIROW academics", can be described as follows: The conclusions of this study are prepared based on the answers to the research problems including: Implementation of the program of strengthening the character education for environmental care for students at Primary SchoolPurwantoro 1 Malang City, 2). Supporting and inhibiting factors in the implementation of the Strengthening Environmental Care Character Education program. The conclusions of this study are as follows: Implementation of the Environmental Care Character Education Strengthening Program in the Faculty of Teachery and Education academic community

The Dean of the Faculty of Teachery and Education socialized the character education strengthening program for environmental awareness to students. The Dean encourages and monitors the implementation of the program and rewards people who have carried out and played a role in the program well. With the Environmental Care Character Education Strengthening Program in the academic community, it is hoped that the academic community can become cultured and environmentally friendly citizens. The dean as the head of the faculty makes a program to strengthen character education for environmental care for the entire academic community with the following steps: (1) forming a faculty team as an effort to strengthen caring character education; (2) mobilizing environmental awareness action activities within the faculty; (3) motivating and encouraging the entire academic community, especially the academic community, to care for the environment as an integral part of strengthening character education; (4) monitoring and evaluating the entire program to maintain and preserve the environment; (5) giving awards to academicians who have participated in environmental conservation programs; (6) establish cooperation with the district municipality's sanitation department and environmental agency within a certain period of time; (7) providing education and training for environmental preservation; (8) establish a waste bank to be managed on a regular basis; (9) cooperating with all stakeholders and companies that are able to become partners in helping to fund activities to maintain and preserve the environment.

Supporting and Inhibiting Factors of the Environmental Care Character Education Strengthening Program for students

a. Supporting factors, the support of the institution that houses this college, the Office of the Environmental Agency of Tuban City and the availability of a Garbage Bank in the campus environment.

b. Supporting factors, the concern of leaders, lecturers and students in greening the campus environment. With high awareness the students brought flower and fruit seeds from home, made a garden in front of each class and held a picket schedule for caring for and watering the garden.

c. There is socialization, education and training on waste management in the form of compost, sorting waste that can still be used 
d. The inhibiting factor is the limited budget from the government in realizing the character education strengthening program for environmental awareness and the low part of the socioeconomic status of the students' parents.

e. Inhibiting factor, there is a small proportion of students who are less enthusiastic in carrying out programs of strengthening character education of environmental concern on a micro and macro scale

f. The awareness of the academic community needs to be increased in the framework of fostering concern for the environment as a strengthening of character education.

\section{REFERENCES}

Abdullah, Mudhofar. 2010. Al-Qur'an dan Konsrvasi Lingkungan (Argumentasi Konservasi Lingkungan Sebagai Tujuan Tertinggi Syari'ah). Jakarta : Dian Rakyat.

Al-Adnani, Abu Fatiah. 2008. Global Warming (Sebuah isyarat dekatnya akhir Zaman dan kehancuran dunia). Jakarta : Granada Mediatama.

Anshoriy, Nasruddin dan Sudarsono. 2008. Kearifan Lingkungan (dalam perspektif budaya jawa), Jakarta : Yayasan Obor Indonesia.

Arif, Ahmad dan Permanasari, Indira. 2009. Hidup, Hirau, Hijau (Langkah menuju hidup ramah lingkungan). Jakarta : Gramedia.

B. Milles, Matthew dan Huberman A. Michael, (2007), Analisis data Kualitatif (terjemahan T. Rohendi Rohidi), Jakarta, UI Press

Canton, James, (2010), The Extreme Future, Jakarta, Pustaka Alvabet

Chang, William, (2009), Bioetika Sebuah Pengantar, Yogyakarta, Kanisius

Daniel, Valerina, (2009), Easy Green Living, Jakarta, Hikmah (PT. Mizan Publika)

Danusaputro, Munadjat, (1984), Hukum Lingkungan dan Pembangunan, Jakarta, Binacipta

Daroeso, Bambang, (1989) Dasar dan Konsep Pendidikan Moral Pancasila,Semarang: Aneka Ilmu

Djamal, Irwan,Zoeraini, (2005), Tantangan Lingkungan dan Landsekap Hutan Kota, Jakarta, Bumi Aksara

Djamal, Irwan, Zoeraini, (2010), Prinsip-Prinsip Ekologi (Ekosistem, Linkungan dan Pelestariannya), Jakarta, Bumi Aksara

Elmubarok, Zaim, (2008), Membumikan Pendidikan Nilai, Bandung, Afabeta

Fuji Raharjo, Imam dan Jawama Adam, Sugayo, (2007), Dialog Hutan Jawa, Mengurai maknna Filosofis PHBM, Yogyakarta, Pustaka Pelajar

Fadeli, Chafid dan Nur Utami, (2008), Audit Lingkungan, Yogyakarta, Gajah Mada University Press

Hariyadi dan B. Setiawan, (2010), Arsitektur, Lingkungan dan Perilaku (Pengantar ke Teori, Metodologi dan Aplikasi), Yogyakarta, Gajah Mada University Press

Iskandar, Johan, (2001), Manusia Budaya dan Lingkungan Ekologi Manusia, Bandung: Humaniora Utama Press

Iskandar, Johan, (1992), Ekologi Perladangan di Indonesia (Studi Kasus: dari daerah Baduy Banten Selatan, Jabar), Jakarta, Djambatan

Jurnal Lingkungan Hidup, (Tahun I-No.1/1994), Jakarta, ICEL K. Dwi Susilo, Rachmad, (2008). Sosiologi Lingkungan, Jakarta: Rajagrafindo Persada

Kaswari, EM.K (1993), Pendidikan nilai memasuki tahun 2000, Jakarta, Grasindo

Khaelany, (1996), Islam, Kependudukan dan Lingkungan Hidup, Jakarta, Rineksa Cipta

Keraf, A. Sonny, (2006) Etika Lingkungan, Jakarta: Penerbit Buku Kompas

Leimona, Beria dan Fauzi, Aunul, (2008), CSR dan Pelestarian Lingkungan, Mengelola Dampak: Positif dan Negatif, Jakarta, Indonesia Business Links

May, Larry dkk, (2001), Etika Terapan I: Sebuah Pendekatan Multikultural, Yogyakarta, Tiara Wacana

May, Larry dkk, (2001), Etika Terapan II: Sebuah Pendekatan Multikultural, Yogyakarta, Tiara Wacana

Mulyana, Rohmat, (2004), Mengartikulasikan Pendidikan Nilai, Bandung, Alfabeta

Mustafa, Zainal EQ, (2009), Mengurai Variabel hingga Instrumen, Yogyakarta, Graha Ilmu

Neolaka, Amos, (2008), Kesadaran Lingkungan, Jakarta, Rineksa Cipta

Riduwan, (2007), Skala pengukuran variabel-variabel Penelitian, Bandung, Alfabeta

Sastrawijaya, Tresna. A, (2009), Pencemaran Lingkungan, Jakarta, Rineka Cipta

Silalahi, M. Daud, (2001) Hukum Lingkungan (dalam Sistem Penegakan Hukum Lingkungan di Indonesia), Bandung, Alumni

Slamet, Y, (1994), Pembangunan Masyarakat Berwawasan Partisipasi, Surakarta, UNS Press

Soemarwoto, Otto, (2008), Ekologi, Lingkungan Hidup dan Pembangunan, Jakarta, Djambatan 
Soeriaatmadja, RE, (1997), Ilmu Lingkungan, Bandung, ITB

Soerjani, Mohamad, (2009). Pendidikan Lingkungan (Environmental Education), Jakarta:UIPress

Sontang Manik, Karden Eddy, (2009), Pengelolaan Lingkungan Hidup, Jakarta: Djambatan

Sugandhy, Aca, dan Hakim, Rustam, (2007) Prinsip dasar Kebijakan Pembangunan Berkelanjutan Berwawasan Lingkungan, Jakarta: Bumi Aksara

Sugiyono, (2009), Memahami Penelitian Kualitatif, Bandung, Alfabeta

Sugiyono, (2009),Metode Penelitian Kuantitatif, Kualitatif dan R\&D, Bandung, Alfabeta

Sulistyaningsih, Tri dan Sunarto, (2009), Pengelolaan Ruang Terbuka Hijau Publik Berbasis Demokratisasi peran actor sebagai upaya mewujudkan Kota berkelanjutandi Malang, Malang, UMM Press

Supardi, Imam, (2003),Lingkungan Hidup dan Pelestariannya,Bandung: Alumni

Suparmi, Niniek, (1994), Pelestarian, Pengelolaan dan Penegakan Hukum Lingkungan, Jakarta, Sinar Grafika

Suparno, Erman, (2010), Grand Strategi Indonesia, Kajian Komprehenship Manajemen Pembangunan Negara-Bangsa), Jakarta, Milestone.

Surakhmad, Winarno, (1998), Penelitian Ilmiah (Dasar, Metode, Teknik), Bandung, Tarsito

Susanta, Gatut dan Sutjahjo, Hari (2008) Apakah Indonesia tenggelam akibat Pemanasan Global, Jakarta: Penebar Pluss

Ward, Barbara dan Dubos, Rene (1980), Hanya Satu Bumi, terjemahan S. Supomo, Bandung, Lembaga Ekologi UNPAD dan Yayasan Ob. 